\title{
Religion as an Indicator of Social Well-Being in Malaysia
}

\author{
Wan Nor Jazmina Wan Ariffin ${ }^{1}$, Norizan Abd Ghani ${ }^{* 1}$, Mohd Fauzi Abd \\ Latip ${ }^{1}$, Wan Abd Aziz Wan Mohd Amin ${ }^{1}$, Wan Mohd Yusof Wan Chik', Fadzli \\ Adam $^{3}$, Jumadil Saputra ${ }^{4}$, Muhammad Ammar bin Abd Wahab ${ }^{1}$
}

\author{
${ }^{1}$ Faculty of Applied Social Sciences, Universiti Sultan Zainal Abidin \\ ${ }^{2}$ Faculty of Islamic Contemporary Studies, Universiti Sultan Zainal Abidin \\ ${ }^{3}$ Research Institute for Islamic Products and Malay Civilization, Universiti Sultan Zainal Abidin, \\ ${ }^{4}$ Faculty of Business, Economics and Social Development, Universiti Malaysia Terengganu, \\ *Corresponding author. Email: norizabd@unisza.edu.my
}

\begin{abstract}
Malaysian Well-Being Index (MyWI) which was introduced in 2013 and Malaysian Well-Being Report portray the determination of the government in the issue of people's well-being regardless of their races. The Malaysian Well-being Report 2013 by the Economic Planning Unit shows that the people's well-being has increased significantly. Several well-being indexes in Malaysia include the Malaysian Well-Being Index (MyWI), Family Well-Being Index (IKK), Malaysia Youth Index and Malaysian Syariah Index were used to measure the people's well-being from various dimensions and consist of different and separate indicators. In this research, five indicators were utilized; 1. Religion and beliefs indicator; 2. Life necessities indicator; 3. Social issues indicator; 4. Social chance or social mobility indicator; and 5. Political and stability indicator. This research serves the purpose of identifying suitable social well-being themes thus analysing the social well-being indicators in Malaysia. Data were collected through structured interview technique using questionnaire and unstructured interviews. Respondents consist of government civil servants and private sector workers as well as T20, M40 and B40 community groups. This research was conducted in 4 zones throughout Malaysia namely North Zone, West/Middle Zone, East Zone and East Malaysia Zone. This survey research uses mixed-methodology technique, that is a combination of qualitative and quantitative research methods. A total of 419 respondents participated in the questionnaire and 15 informants were involved in unstructured interviews. Finding reveals that religion and beliefs is the most relevant element to be used as an indicator of social well-being among the society.
\end{abstract}

Keywords: Religion, Well-Being Indicator, Social Well-Being, Life Necessities, Malaysia

\section{INTRODUCTION}

Well-being in Malaysia is not a current issue. Social wellbeing is a life goal desired by individuals, families, communities and nation. It is the key element in determining the level of development in a community or country. The concept of social well-being illustrated that the strategies to transform a community include the aspects of social issues management, fulfilment of life necessities and provision of social mobility in a community. The comprehension to these three elements of social well-being shall aid the policy makers and program executioners in order to ease the effort to enhance the well-being of individuals, families and communities. The existence of these three social well-being elements shall provide the community with a secured and safe environment to live in, full satisfaction towards basic needs and necessities, and maximized the chance of social mobility. Thus, members of the community are free to develop self potential, to involve actively in activities held in all social, economical and political aspects, and to give back to the society, religion, and nation. 
Studies on the social and life well-being generally been conducted for centuries. Social well-being is usually determined through three fundamental elements that are; 1 . Social issues management; 2 . fulfilment of life necessities; and 3. provision of social mobility in a community [1]. The term 'social well-being' means individual (in group) satisfaction towards social status, welfare, living standards and individual's quality of life [2]. Social well-being, is defined by Keyes (1998) [3] as an evaluation on the condition and functions of a person in a society, stating that life has its social properties and its challenges is seen as a criteria to achieve a better quality of life [4]. The United Nations Research Institute for Social Development [5] has listed out nine aspects that need to be fulfilled in order to attain social well-being [6]. The nine aspects consist of nutrition, protection, health, education, recreation, safety and security, social stability, physical environment and excess income.

Nevertheless, well-being is not measured based only on objective dimension, but also includes subjective dimension. Norizan (2003) [7] divided well-being in life into two categories that are; 1 . Objective quality of life; and 2. Subjective quality of life. Objective quality of life relates to life necessities that can be accomplished by individuals and is observable such as wealth, health and education. Meanwhile, subjective quality of life refers to self actualization and satisfaction attained by a person like the pleasure of securing a job, being grateful with the children's achievements and successes and having a happy family. Well-being in life is also linked to matters that allow individuals to enjoy pleasure, happiness and meaning in life (Renwick, 2006) [8]. Well-being in life is basically an effort to overcome problems and enrich the human life quality until they are in a safe, secured and comfortable condition physically, socially or psychologically [9].

Human Development Index (HDI) is one of the indicators and is applicable to analyze social and economical development of a country and also identify the human development in a country. Apart from HDI as an alternative, few other indexes were developed to measure the level of social well-being. Among the indexes include Life Quality Index (LQI), Happiness Index, and Meaning in Life Index (MILI). Dar (2004) [10] has introduced the Ethics-Augmented Human Development Index (E-HDI) that is based on Maqasid Syariah and taken into account the transformation and development for all countries while Anto (2009) [11] has been developing the Islamic Human Development Index (I-HDI) that comprises of the Material Welfare Index (MWI) and Non-Material Welfare Index (NWI), where it represents the five pillars in Maqasid Syariah. Rehman \& Askari (2010) [12], on another note, have presented the Islamicity Index (I2) to serve the purpose of measuring the level of "islamicity" in a Muslim and non-Muslim countries based on the principles of Islam.

The influence of religious elements are often related as one of the factor that affect well-being in life of individuals, communities and nation. Hairunnizam Wahid, Sanep Ahmad \& Radiah Abdul Kader (2011) [13] have conducted a research on the influence of religious factor towards the quality of life of individuals and found that religious factor is fundamental because it has the ability to affect mental health, to positively change attitudes and behaviours of individuals towards a better life, and eventually transform the economy and lifestyle of individuals in long term.

Hairunnizam (2010) [14] stated that few researchers have conducted studies on the relationship between religious commitments towards well-being in life of individuals. For example, Ellison (1991) [15] in his research in the United States of America revealed that the involvement of individuals in religious organizations and high levels of religious beliefs would boost the level of satisfaction on their quality of life. This is further supported by Schieman et. al. (2003) [16] who pointed out that religious values in individuals would guide and control their lives, influence them to actively strive to attain their goals without only relying on luck, destiny and fate. In other words, religious aspects is seen as an important element for its effects on mental health and self motivation of individuals that would lead to the enhancement of their life satisfaction.

Developmental process begins with moral, spiritual and human mental progress that would be the agent to its physical self, environment and economy [17]. There are also studies on the relations of religious commitments towards psychological well-being initiated by Hapsarini Nelma, Dini Rahma \& Fivi Nurwiyanti (2012) [18]. The research highlighted that there is a signicant relationship between psychological well-being and religious commitments on societies. The study also revealed that there is a positive correlation between religious commitment and personal growth dimensions, and stressed that the purpose of psychological well-being is caused by the religion that has the orientation which would guide individuals on how to perceive the world, assist them to define reality and give meaning to life. In short, the study presented that individuals with high religious commitments would possess high psychological wellbeing.

Essential psychological well-being aspects such as life satisfaction, loneliness, and anxiety were taken into account to portray the relationship between religion and psychological well-being. According to Ismail (2012) [19] who has been operating religion as a religious belief, frequency of prayers, and meet-ups in mosques for prayers, found out that there is a positive relationship between religion and life satisfaction, and a negative relationship between religion and loneliness and anxiety. Studies on the importance of religion in the aspect of wellbeing in life is also discussed by Ibrahim (2016) [20], who disclosed that individuals that have greater sense of religious identity may increase the well-being along with racial identity that a person perceives for higher public regard. Nevertheless, the research has not includes the religious influence and its dimensions with social wellbeing. Thus, it is essential to assess how every aspects of religion relates to social well-being. 


\section{RESEARCH METHODOLOGY}

This research adopts a mixed-methodology technique that combines qualitative method and quantitative method to obtain data. Data collection done in this research employs primary and secondary sources. For primary data collection, various techniques were applied including stuructured interviews using questionnaires as well as unstructured interviews. Face to face interviews were conducted with respondents identified from the groups of chosen respondents to support the data. A set of questionnaire comprising of several identified items based on the research objectives were distributed to a total of 419 respondents selected using a purposive sampling method. Areas and research sampling framework covered four zones in Malaysia namely North Zone, East Coast Zone, West/Middle and East Malaysia Zone (Sabah and Sarawak) as shown in Table 1. On the division of total respondents in each zone, a number of 104 respondents are from the North Zone, 108 respondents from the Middle Zone, 101 respondents from East Coast Zone, and 106 respondents from East Malaysia Zone. Percentage of respondents for each zone is $25 \%$ altogether.

Table 1 Demografic Information of Quantitative Respondents

\begin{tabular}{llll}
\hline Zones & North Zone & 104 Respondents & $24.82 \%$ \\
West/Middle Zone & 108 Respondents & $25.77 \%$ \\
East Coast Zone & 101 Respondents & $24.10 \%$ \\
East Malaysia Zone & 106 Respondents & $25.29 \%$
\end{tabular}

Research population is respondents that consists among T20 group (monthly income over RM13,000), M40 (monthly income between RM3500 to RM12,000) and B40 (monthly income of less than than RM3,000). The use of questionnaire in this study is divided few sections namely Section A: socio-demographic and Section B: social well-being indicator that includes several items; religious care and beliefs, social issues, life necessities, social mobility and chances, and political and stability item.
A 7-point likert scale is applied for the purpose of this study. The 7-point scale is selected for this study as it is often used and has the best features [21] apart from its ability to measure attitude consistently [22]-[23]. To determine the level of well-being, mean value is divided into three stages, that are; low level, average level, and high level [24]-[27].

Table 2 Social Well-Being Level Score

\begin{tabular}{cc}
\hline Mean Score Range & Well-Being Level \\
\hline $0-2.3$ & Low \\
$2.4-4.7$ & Average \\
$4.8-7.0$ & High \\
\hline
\end{tabular}

Table 2 displays the score range values for social wellbeing in this study. If the mean value for social well-being indicator is between $0-2.3$, then the level of social wellbeing is at a low level. Meanwhile, mean value ranging from 2.4-4.7 shows that social well-being is at its average level. A mean value of 4.8-7.0, on the other hand, indicates that social well-being is at a high level. Quantitative data obtained from the questionnaire are then analyzed using SPSS software while the qualitative data collected through interview methods are transcribed and analyzed to support the quantitative data findings.

\section{RESEARCH FINDINGS}

To serve the purpose of this study, a number of social well-being indicators have been identified and adapted to fulfil the objectives of the study. Among the indicators used are religious care, life necessities, social issues, social chances/social mobility, and politics and stability. Mean scores for all indicators are shown in Table 3 below. The indicator which possesses the highest mean value is social chances with a score of 6.54 , followed by religion and beliefs indicator with a 6.45 score. Meanwhile, the mean values for politics and stability, life necessities and social issues are 6.15, 6.12 and 5.62 respectively.

Table 3 Mean Average of Social Well-Being Level in Malaysia

\begin{tabular}{lccccc}
\hline Indicator & North Zone & Middle Zone & East Coast Zone & $\begin{array}{c}\text { East Malaysia } \\
\text { Zone }\end{array}$ & Overall \\
\hline Religion and & 6.49 & 6.21 & 6.47 & 6.62 & 6.45 \\
Beliefs & 6.12 & 6.02 & 6.05 & 6.29 & 6.12 \\
Life Necessities & 5.58 & 5.45 & 5.53 & 5.91 & 5.62 \\
Social Issues & 6.55 & 6.45 & 6.47 & 6.70 & 6.54 \\
Social Chances & 6.20 & 6.05 & 5.97 & 6.38 & 6.15 \\
Politics and & & & & & \\
Stability & & &
\end{tabular}


Table 4 Research Findings through Interview Methods

\begin{tabular}{ll}
\hline Issues & Respondents \\
\hline Religion as the core of life & $\begin{array}{l}\text { R14,R1, R4, } \\
\text { R6, R8, R9, } \\
\end{array}$ \\
& R11 \\
\hline $\begin{array}{l}\text { Harmonious religious freedom guarantees } \\
\text { well-being/ religious conflicts need to be } \\
\text { avoided }\end{array}$ & $\mathrm{R} 2, \mathrm{R} 3, \mathrm{R} 12, \mathrm{R} 4$, \\
\hline $\begin{array}{l}\text { Individual roles in ensuring that religion } \\
\text { leads to well-being }\end{array}$ & $\mathrm{R} 14, \mathrm{R} 3, \mathrm{R} 4$, \\
\hline $\begin{array}{l}\text { Government roles in ensuring that religion } \\
\text { leads to well-being }\end{array}$ & $\mathrm{R} 9, \mathrm{R} 11$ \\
\hline
\end{tabular}

On another note, the mean scores according to zones display the highest value in East Malaysia Zone (6.62), followed by North Zone (6.49), East Coast Zone (6.47), and Middle Zone (6.21). From the mean values shown, religion and belief are the indicator that gets the second highest mean value, which is 6.45 . This indicate the religious factor is very important element in the human life which in turn can help improve the level of social wellbeing. In line with the nature of human life itself which requires beliefs and religious as a guidance in the daily life.

Qualitative data findings were also obtained from this study through interviews conducted with a number of respondents regarding the element of religion as an indicator for well-being in life. Research findings discovered that religion is indeed an essence of life in the society in general and is an indicator of social well-being in this country. A total of 14 respondents were interviewed and they believed that each individual yearns for religion as the basis and core in their lives. To summarize, the findings obtained through interview methods are illustrated in Table 4.

Summary of the interviews conducted indicated that respondents agreed that religion is an essential element in life and has effects on the social well-being of individuals and society.

"Religious belief is the basis for references and guidelines in people's lives. Every religion encourages harmonious living in a plural society.

This fundamental faith in religion could secure the well-being of the people and society."

$\mathrm{R} 14, \mathrm{~T} 1$

Religion has to be uphold by all parties regardless of their differences for when there is zero tolerance between religions, it would eventually demolish the well-being in life. In Malaysian context as a multiethnic and multiracial country, diversity in religions is a uniqueness and an exclusivity, not a threat that might initiate conflicts. Nevertheless, it needs to be well governed to reduce the risks of religious distinction conflicts among society.

"Should we observe carefully, some races may they be Chinese, Indians or Malays, and other religions are all decent. It depends on each individual to uphold and maintain their well-being. If they don't raise issues that involve racial tensions, with God's willing, the well-being of the multiracial society shall be (good)."

R6, T1

Interviews with respondents also presented that in order to maintain the stability of social well-being through religion and beliefs, each individuals need to appreciate their respective religious values and play their roles in ensuring that the religious sensitivities of each race is protected. This effort should then be further enhanced with the roles of the authorities that enforce laws and in maintaining religious sensitivities of each race. These are essential to maintain social well-being in Malaysia.

\section{DISCUSSION}

The well-being concept in life is dynamic in nature, that determines whether our progress in life is heading towards the better or worse. Well-being in life has multiple dimensions but usually measured through economic indicator that hails from income generation [28]. However, well-being in life can be assessed subjectively. Subjective assessment covers broader and more comprehensive aspects such as income and distribution, work environment, transportation and communication, health, education, housing, environment, and life [7].

On discussing the well-being in life, other elements like nutrition, shelter, health, education, recreation, safety, social stability, and physical environment are also required in determining the well-being of individuals and society. Aside from the above-mentioned elements, findings of this study proved that the element of religion is also one of the indicators in improving well-being in life. As in previous researches, religions have great influence on well-being in life. Research has shown that individuals who practice religious rituals and prayers enjoy high level of well-being in their lives (Diemer et. al.,2011; Hackney \& Sanders, 2003; Oishi \& Diener, 2014) [29]-[31]. Religion is also observed as an effective mechanism to overcome stresses 
in life and is regarded as a system to provide meaning in life [32].

Findings of the study revealed that religion is accepted as the key element of well-being in life. The society admitted that their beliefs to the religion are the utmost important aspect that needs to be emphasized to ensure a secured life. In the context of Malaysia as a multiethnic country, religion is still the core to the lives of all individuals regardless of their races and cultures. Religious element is desired in life not only to assist humans to find their way to God but to also contribute in well-being in life. Parallel to the findings of this study, the high mean value obtained proved that the society placed the religion at its highest level in their lives. Apart from other elements such as life necessities, social issues, social chances, and political stability, religion as well is an indicator in determining the level of social well-being of individuals and society.

In in-depth interviews with several of the respondents, most of them admitted that religion is the most fundamental element in life. Since religion is regarded as the basis of well-being in life, the position of religion as an indicator for well-being in life has to be managed well by the goverment. Added by the current situation in the country, religious element needs to be well taken care of since in Malaysia, ethnics and religions have been the group identity that correlate with one another and often associated ethnic groups with the religions they embraced or professed. As such, ethnic relation stability in this country is closely related to the element of religion.

In order to implement the social well-being of the society through religious element, all parties need to play their parts. The role of the government in maintaining the religious stability in the country is seen as an utmost important task for religion is regarded as an issue that could lead to racial tensions when religious sensivities are not well taken care of. Apart from the government, each individual needs to play his or her role seriously in religious practices and not to ever deals with religious issues that would cause racial provocations. Each individual needs to acknowledge and respect religious differences in this country and perform religious practices in harmony.

\section{CONCLUSION}

Well-being is the most sought after matter by indiciduals. In the process to improve well-being, several items need to be taken into account and should be emphasized. In Malaysia, a number of indexes have been developed to demonstrate the level of its people well-being that includes various indicators. This study also shows that the element of religion and beliefs is one the indicator to determine the state of social well-being of people. Therefore, it is suggested that future follow-up researches on the aspect of religion as the determinant of well-being in life would be conducted thoroughly and explicitly.

\section{ACKNOWLEDGMENT}

This paper is a research outcome from the "Pembangunan Model Kesejahteraan Sosial di Malaysia berasaskan Maqasid Syariah" project funded by the Fundemental Research Grantt Scheme (FRGS) RR278, Universiti Sultan Zainal Abidin (UniSZA), Terengganu. Utmost appreciation goes to the Ministry of Higher Education, Malaysia and Universiti Sultan Zainal Abidin (UniSZA) on the funds granted for this project.

\section{REFERENCES}

[1] J. Midgley, Social development: The developmental perspective in social welfare. Sage. 1995.

[2] L. Ivankina and V. Ivanova, Social well-being of elderly people (based on the survey results). In $S H S$ Web of Conferences 28 (01046) (2016). EDP Sciences.

[3] C. L. M. Keyes Social well-being. Social psychology quarterly, (1998) 121-140.

[4] A. Lages, E. Magalhães, C. Antunes and C. Ferreira, Social well-being scales: validity and reliability evidence in the Portuguese context. Social well-being scales: validity and reliability evidence in the Portuguese context, (2) (2018) 15-26.

[5] Kuklinski, A. United Nations Research Institute for Social Development-Geneva. 1966.

[6] Z. A. Wahab, Kesejahteraan sosial komuniti pesisir: kajian kes di Kampung Nelayan Kandis Bachok dan Kampung Baru Nelayan, Tumpat Kelantan (Doctoral dissertation, Universiti Malaysia Kelantan). 2015.

[7] N. A. Ghani, Kualiti hidup penduduk Pulau Negeri Terengganu (Doctoral dissertation, Fakulti Sains dan Teknologi). 2003.

[8] Renwick, R., The Quality Life Model. 2006.

[9] M. F. Nurdin, Penilaian dampak pembangunan ke arah kesejahteraan masyarakat: Penilaian dampak sosial. Kuala Lumpur: Utusan Publication \& Distributor. 2003.

[10] H. A. Dar, On making human development more humane. International Journal of Social Economics. 2004.

[11] M. B. Anto, Introducing an Islamic human development index (I-HDI) to measure development in OIC countries. Islamic Economic Studies, 130(542) (2011) 1-54.

[12] Rehman \& Askari, An economic Islamic city index $\left(\mathrm{EI}^{2}\right)$. Global Economy Journal. 10(3) (2010). 
[13] W. Hairunnizam, A. Sanep and A. K. Radiah, Lokalisasi pengagihan zakan dan cadangan khidmat sosial: satu tinjauan awal. Borderless Economy: Oppurtunities and Challenges for Business in Southeast Asia, Universit of Bengkulu, Indonesia. 2011.

[14] W. Hairunnizam and R. A. Kader, Pengaruh Faktor Keagamaan Terhadap Kualiti Hidup Individu: Kajian Kes Asnaf Fakir dan Miskin. In Seminar Kebangsaan MACFEA ke-14: Hala tuju Penyelidikan Kepenggunaan. (2010) 13-14.

[15] C. G. Ellison, Religious involvement and subjective well-being. Journal of health and social behavior, (1991) 80-99.

[16] S. Schieman, Socioeconomic status, job conditions, and well-being: Self-concept explanations for gender-contingent effects. The Sociological Quarterly, 43(4) (2002) 627-646.

[17] R. Mohamed and S. A. B. Abu, Pembangunan masyarakat ke arah kesejahteraan berteraskan pembangunan insan. 2010.

[18] H. Nelma, D. R. Bintari and F. Nurwiyanti, Hubungan Komitmen Beragama Dengan Kesejahteraan Psikologis Pada Masyarakat Jakarta Usia Dewasa. Jurnal Psikologi: PITUTUR, 1(1) (2012) 4152.

[19] Z. Ismail and S. Desmukh, Religiosity and psychological well-being. International Journal of Business and Social Science, 3(11)(2012).

[20] M. H. Ibrahim, Religion and Well-being: Differences by Identity and Practice. 2016.

[21] M. V. Blerkom, Measurement and statistics for teachers. New York: Rotledge.2009.

[22] F. J. Fowler Jr, Survey research methods. Sage publications. 2013.

[23] N. Sriratanaviriyakul and J. El-Den, Pedagogical Discussion Cases in Higher Education: The Role of Knowledge Sharing in Students' Learning. Procedia Computer Science, 161 (2019) 215-225.

[24] Z. Copur, Handbook of Research on Behavioral Finance and Investment Strategies: Decision Making in the Financial Industry: Decision Making in the Financial Industry. IGI Global. 2015.

[25] B. Finlay and A. Agresti Statistical methods for the social sciences. Dellen. 1986.

[26] Zainudin Abu Bakar et al, Kemahiran ICT guru pelatih Universiti Teknologi Malaysia. Prosiding
Seminar Kebangsaan JPPG 2007. 18 - 20 November 2007. Royal Adelphi, Seremban. 2007.

[27] A. S. Shaari, A. Yusof, M. K. Jamal Khan, S. M. Tang and K. T. Lim, Keadilan penilaian prestasi dalam kalangan guru dan hubungannya dengan motivasi kerja dan prestasi akademik sekolah. International Journal of Management Studies (IJMS), 15 (2008) 159-176.

[28] F. Nimpagaritse and D. Culver, A broader perspective of measuring the well-being of rural farm and non-farm households. 2010.

[29] Diemer, E., Tay. L., \& Myers, D. G., The religion paradox: if religion makes people happy, why are so many dropping out? Journal of Personality and Social Psychology, 101 (2011), 1278-1290.

[30] C. H. Hackney and G. S. Sanders, Religiosity and mental health: A meta-analysis of recent studies. Journal for the scientific study of religion, 42(1) (2003) 43-55. doi:10.1111/14685906.t01-1-00160

[31] S. Oishi and E. Diener, Residents of poor nations have a greater sense of meaning in life than residents of wealthy nations. Psychological Science, 25(2) (2014) 422-430.

[32] C. L. Park, Religion and meaning. In R. F. Paloutzian \& C. L. Park (Eds.), Handbook of the psychology of religion and spirituality (pp. 295-314). New York, NY: Guilford Press. 2005. 